ORIGINAL ARTICLE

\title{
An Assessment of Retinopathy in Type-II Diabetics along with Microalbuminuria
}

\author{
MUHAMMAD ZAFAR IQBAL ${ }^{1}$, MUHAMMAD KHALID ${ }^{2}$, MUHAMMAD HAROON BILAL ${ }^{3}$ \\ ${ }_{1,3}$ Associate Professor, Department of Medicine, DG Khan Medical College, DG Khan \\ ${ }^{2}$ Professor, Department of Ophthalmology, Sahiwal Medical College Sahiwal \\ Correspondence to: Dr. Muhammad Khalid, Email: Khalidvision@hotmail.com, Cell: 03017730748
}

\begin{abstract}
Objective: To assessment of retinopathy in type-II diabetics along with microalbuminuria at tertiary care hospital. Material and methods: This study was done at Department of Medicine, D.G Khan Hospital, D.G Khan from April 2020 to October 2020 over the period 6 months. Total 295 patients of type-II diabetes mellitus along with microalbuminuria having age between $45-80$ years either male or female were selected. Diabetic retinopathy was evaluated in selected patients.

Results: Total 295 patients were selected according to inclusion criteria. The mean age of patients was $58.13 \pm$ 9.412 years. Out of 295 patients, retinopathy was noted in $67(23 \%)$ patients. Out of $147(49.83 \%)$ male patients, retinopathy was noted in $39(26.5 \%)$ patients. Out of $148(50.17 \%)$ female patients, retinopathy was noted in 28 $(18.9 \%)$ patients. Statistically insignificant association of retinopathy with gender was noted with $p$ value 0.119 .

Conclusion: Findings of this study showed a higher percentage of retinopathy in patients of type-II diabeties along with microalbuminuria. Most of the victims were males as compared to females and no association of development of retinopathy with gender was detected. Higher number of patients belonged to $4^{\text {th }}$ and $5^{\text {th }}$ decade of life. Four to five years of duration was noted among the half of the study population.

Keywords: Retinopathy, Diabetes mellitus type II, Microalbuminauria
\end{abstract}

\section{INTRODUCTION}

According to International Diabetic Federation (IDF) database, Pakistan stands on $7^{\text {th }}$ number in list of countries where diabetes mellitus (DM) rate are high. In 2007, about 6.9 million population was suffering from DM. ${ }^{2}$ In different studies conducted by Diabetic Association of Pakistan, $10 \%$ of peoples aged $\geq 30$ years were suffering from type-II DM. In $3^{\text {rd }}$ world countries like Pakistan, undiagnosed diabetes and related retinopathy because of virtually nonexistent primary eye care setups in general population, is related with the impaired visual status of community. ${ }^{3}$ There is an association between microvascular complication and DM. With advancing age, it is the main cause of visual loss. 4 Cardiovascular diseases are the leading cause of mortality in type-II DM, despise of mortality and morbidity of neuropathy, nephropathy and retinopathy. ${ }^{6}$ The gradual progression of retinopathy involves mild abnormalities growing into proliferative retinopathy. Glaucoma, retinal detachments and hemorrhages and blindness may become its ending result. Determents for developing DR include diabetes. Micro-albuminuria, lipids, smoking, BMI, hypertension, age duration of diabetes and gender are the causes DR. ${ }^{7}$ Life style changes like diet, physical exercises and oral hypoglycemic agents are the most effective management of type-II diabetics. Foot care, retinopathy, nephropathy monitoring and peripheral diabetic neuropathy should also be acknowledged as health issues. Important parameters in disease management including $\mathrm{HbA1C}$, blood glucose level and high postprandial serum glucose can be lowered by many available oral hypoglycemic agents. FDA has approved many oral hypoglycemic agents that are efficient in cases of type-ll diabetes cases. Patient's cofactors, contraindicating disease, tolerability

Received on 13-02-2021

Accepted on 09-06-2021 and side effect profile play a significant role in selecting the best agent. ${ }^{8}$

\section{MATERIALS AND METHODS}

This was a cross sectional study done at Department of Medicine, D.G Khan Hospital, D.G Khan from April 2020 to October 2020 over the period 6 months. Total 295 patients of type-Il diabetes mellitus along with microalbuminuria having age between 45-80 years of both gender were selected. Prior permission was taken from hospital committee. Already diagnosed and under treatment patients for diabetic retinopathy (on history and medical record), already under treatment for microalbuminuria (on history and medical record), not willing to participate in the study and hypertensive patients with retinopathy were excluded from the study.

History of all the patients was taken and routine investigation was done. Than all the patients were assessed by a senior consultant ophthalmologist for diabetic retinopathy. Findings were noted on proforma.

Computer software SPSS was used to analyzed the collected data. Age was presented as Mean and SD. Gender and diabetic retinopathy were presented as frequencies and percentages. Chi-square teas used to detect the association of diabetic retinopathy with age group, gender and duration of diabetes mellitus.

\section{RESULTS}

Total 295 patients were selected according to inclusion criteria. The mean age of patients was $58.13 \pm 9.412$ years. Out of 295 patients, retinopathy was noted in 67 (23\%) patients. (Fig. 1)

Out of $147(49.83 \%)$ male patients, retinopathy was noted in $39(26.5 \%)$ patients. Out of $148(50.17 \%)$ female patients, retinopathy was noted in 28 (18.9\%) patients. 
Association between $\mathrm{DR}$ and gender was not significant $(\mathrm{P}$ $=0.119$ ) statistically. (Table 1 )

Three age groups were created i.e. age group 45-57 years, age group 58-68 years and age group 69-80 years. Total $148(50.17 \%)$ patients belonged to age group $45-57$ years and retinopathy was noted in $36(24.3 \%)$ patients. Out of $100(33.90 \%)$ patients of age group 58-68 years, retinopathy was seen in $19(16 \%)$ patients. Out of 47 $(15.93 \%)$ patients of age group $69-80 \%$ ) patients, retinopathy was noted in $12(25.5 \%)$ patients. Association between DR and age groups was not significant $(P=$ 0.544). (Table 2)

Out of $129(43.73 \%)$ patients of $1-3$ years duration of DM group, retinopathy was noted in $31(24.00 \%)$ patients. Among the $166(56.27 \%)$ patients of $4-5$ years of duration of DM, retinopathy was noted in $36(21.7 \%)$ patients. Statistically insignificant association of retinopathy with duration of DM was noted with p value 0.634 . (Table 3)

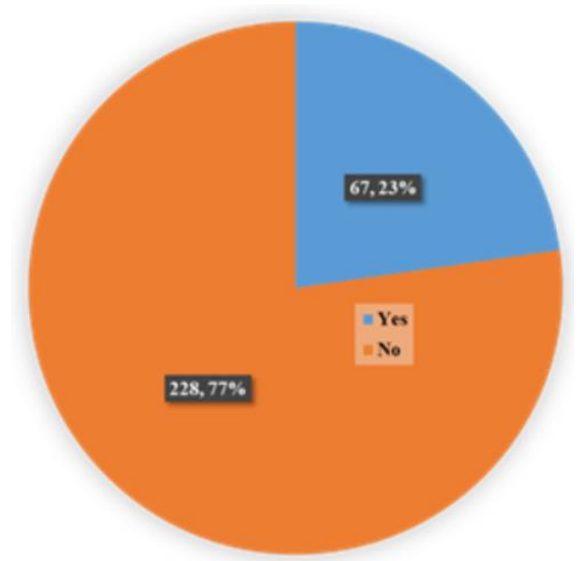

Figure 1: Frequency of retinopathy

Table 1: Association of retinopathy with gender

\begin{tabular}{|c|c|c|c|c|}
\hline \multirow{2}{*}{ Gender } & \multicolumn{2}{|c|}{ Retinopathy } & \multirow{2}{*}{ Total } & \multirow{2}{*}{$p$-value } \\
\hline & Yes & No & & \\
\hline Male & $\begin{array}{l}39 \\
26.5 \%\end{array}$ & $\begin{array}{l}108 \\
73.5 \%\end{array}$ & $\begin{array}{l}147 \\
(49.83 \%)\end{array}$ & \multirow{3}{*}{0.119} \\
\hline Female & 28 . & $\begin{array}{l}120 \\
81.1 \%\end{array}$ & $\begin{array}{l}148 \\
(50.17 \%)\end{array}$ & \\
\hline Total & $\begin{array}{l}67 \\
22.7 \%\end{array}$ & $\begin{array}{l}228 \\
77.3 \% \\
\end{array}$ & 295 & \\
\hline
\end{tabular}

Table 2: Association of retinopathy with age group

\begin{tabular}{|c|c|c|c|c|}
\hline \multirow{2}{*}{ Age groups } & \multicolumn{2}{|c|}{ Retinopathy } & \multirow{2}{*}{ Total } & \multirow{2}{*}{$p$-value } \\
\hline & Yes & No & & \\
\hline $45-57$ & $\begin{array}{l}36 \\
24.3 \%\end{array}$ & $\begin{array}{l}112 \\
75.7 \%\end{array}$ & $\begin{array}{l}148 \\
50.17 \%\end{array}$ & \multirow{4}{*}{0.544} \\
\hline $58-68$ & $\begin{array}{l}19 \\
19.0 \%\end{array}$ & $\begin{array}{l}81 \\
81.0 \%\end{array}$ & $\begin{array}{l}100 \\
33.90 \%\end{array}$ & \\
\hline $69-80$ & $\begin{array}{l}12 \\
25.5 \%\end{array}$ & $\begin{array}{l}35 \\
74.5 \%\end{array}$ & $\begin{array}{l}47 \\
15.93 \%\end{array}$ & \\
\hline Total & $\begin{array}{l}67 \\
22.7 \%\end{array}$ & $\begin{array}{l}228 \\
77.3 \%\end{array}$ & 295 & \\
\hline
\end{tabular}

Table 3: Association of retinopathy with duration of DM

\begin{tabular}{|l|l|l|l|l|}
\hline \multirow{2}{*}{$\begin{array}{l}\text { Duration of DM } \\
\text { (Years) }\end{array}$} & \multicolumn{2}{|l|}{ Retinopathy } & \multirow{2}{*}{ Total } & \multirow{2}{*}{ p-value } \\
\cline { 2 - 4 } $1-3$ & Yes & No & & \\
& 21 & 98 & 129 & \\
\hline \multirow{2}{*}{$4-5$} & $24.0 \%$ & $76.0 \%$ & $43.73 \%$ & \multirow{3}{*}{$\mathbf{0 . 6 3 4}$} \\
\hline \multirow{2}{*}{ Total } & 36 & 130 & 166 & \\
& $21.7 \%$ & $78.3 \%$ & $56.27 \%$ & \\
\hline
\end{tabular}

\section{DISCUSSION}

The purpose of the present study was to assessment of retinopathy in type-II diabetics along with microalbuminuria at tertiary care hospital. In our study, mean age of patients was $58.13 \pm 9.412$ years. Out of 295 patients, retinopathy was noted in 67 (23\%) patients. Out of 147 (49.83\%) male patients, retinopathy was noted in $39(26.5 \%)$ patients. Out of $148(50.17 \%)$ female patients, retinopathy was noted in $28(18.9 \%)$ patients. Statistically insignificant association of retinopathy with gender was noted with $p$ value 0.119 . In one study by Li $\mathrm{N}$ et al $^{14}$ out of 1100 patients, DR was noted in $32.1 \%$ patients which is comparable with our study. Similarly Jammal $\mathrm{H}$ et $\mathrm{al}^{15}$ reported frequency of $\mathrm{DR}$ as $7.9 \%$. In study of Kostev $\mathrm{K}$ et $\mathrm{al}^{16}$ out of 12,524 patients of type-II diabetes mellitus, DR was noted in $19 \%$ patients. Looker HC et $\mathrm{al}^{17}$ reported prevalence of DR as $19.3 \%$. In another study conducted by Buková $L$ et al ${ }^{18}$ showed that DR was found in $0.85 \%$ male patients and $1.2 \%$ in female patients. A study conducted by Al-Zuabi $\mathrm{H}$ et $\mathrm{al}^{19}$ showed that out of the 92 diabetics, DR was present in $7.6 \%$ patients. In a local study conducted in Karachi by Mahar PS et $\mathrm{al}^{20}$ found DR in $27.43 \%$ patients out of 19211 patients. In another local study conducted by Hayat AS et $\mathrm{al}^{21}$ total 100 patients were selected. Mean age of the patients was mean age $45.1 \pm 3.2$ years. Among these $40 \%$ patients were males and rest were females. DR was seen in $17 \%$ patients. Manaviat $\mathrm{MR}$ et $\mathrm{al}^{22}$ reported frequency of DR as $39.3 \%$.

The variation in rates could be as a result of the different methods used in those studies, the population and or the races involved, or variations in controlling blood sugar levels. Cross sectional studies, referral biases and small sample size are major limitations due to which findings are very difficult to generalize in large populations. Its strength lies in the fact that this is a first study of its kind which planned to assess the frequency of DR in population our area by using photographs of retina and standard grading technique.

\section{CONCLUSION}

Findings of this study showed a higher percentage of retinopathy in patients of type-II diabeties along with microalbuminuria. Most of the victims were males as compared to females and no association of development of retinopathy with gender was detected. Higher number of patients belonged to $4^{\text {th }}$ and $5^{\text {th }}$ decade of life. Four to five years of duration was noted among the half of the study population.

\section{REFERENCES}

1. Giannini C, Caprio S. Type II Diabetes Mellitus and Obesity in Youths. Contemporary Endocrinology. 2013;4:523-35.

2. Hove MN, Kristensen JK, Lauritzen T, Bek T. The prevalence of retinopathy in an unselected population of type 2 diabetes patients from Arthus County, Denmark. Acta Ophthalmol Scand. 2004;82:443-8.

3. Shera AS, Rafique G, Khwaja IA, Ara J, Baqai S, King H. Pakistan National Diabetes Survey: prevalence of glucose intolerance and associated factors in Shikarpur, Sindh province. Diabet Med. 1995;12:1116-21.

4. Tian C, Fang S, Du X, Jia C. Association of the C47T polymorphism in SOD2 with diabetes mellitus and diabetic 
microvascular complications: a meta-analysis. Diabetologia. 2011;54(4):803-11

5. Wahab S, Mahmood N, Shaikh Z, Kazmi WH. Frequency of retinopathy in newly diagnosed type 2 diabetes patients. $\mathrm{J}$ Pak Med Assoc. 2008;58:557.

6. Lyssenko V, Almgren P, Anevski D. Genetic prediction of future type 2 diabetes. PLOS Med. 2005;2:345-8.

7. Cikamatana L, Mitchell P, Rochtchina E, Foran S, Wang JJ. Five-year incidence and progression of diabetic retinopathy in a defined older population: the Blue Mountains Eye Study. Eye. 2007;465-71.

8. Nelson P. The incretin mimetic exenatide as a monotherapy in patients with type 2 diabetes. Diabetes Technol Ther. 2007;9(4): 317-26.

9. Tapp RJ, Shaw JE, Harper CA, De Courten MP, De Courten MP, Balkau MP. AusDiab Study Group: The prevalence of and factors associated with diabetic retinopathy in Australian population. Diabetes Care. 2003;26:1731-7.

10. Kalvoda B. Screening for diabetic retinopathy in Czech Republic guidelines. Cesk Slov Oftalmol. 2002;8:3-10.

11. Chowdhury TA, Lasker SS. Complications and cardiovascular risk factors in South Asians and Europeans with early-onset type 2 diabetes. QJM. 2002;95(4):241-6.

12. Weerasuriya N, Siribaddana S, Dissanayake A, Subasinghe Z, Wariyapola D, Fernando DJ. Long-term complications in newly diagnosed Sri Lankan patients with type 2 diabetes mellitus. QJM. 1998;91(6):439-43.

13. Ramavat PR, Ramavat MR, Ghugare BW, Vaishnav RG, Joshi MU. Prevalence of Diabetic Retinopathy in Western Indian Type 2 Diabetic Population: A Hospital - based Cross - Sectional Study. J Clin Diagn Res. 2013;7(7):1387-90.

14. Li N, Yang XF, Deng Y, Gu H, Ren XT, Xu J. Diabetes selfmanagement and its association with diabetic retinopathy in patients with type 2 diabetes. Zhonghua Yan Ke Za Zhi. 2013 Jun;49(6):500-6.

15. Jammal $\mathrm{H}$, Khader $\mathrm{Y}$, Alkhatib $\mathrm{S}$, Abujbara $\mathrm{M}$, Alomari $\mathrm{M}$, Ajlouni K. Diabetic retinopathy in patients with newly diagnosed type 2 diabetes mellitus in Jordan: prevalence and associated factors. J Diabetes. 2013;5(2):172-9.

16. Kostev K, Rathmann W. Diabetic retinopathy at diagnosis of type 2 diabetes in the UK: a database analysis. Diabetologia. 2013;56(1):109-11.

17. Looker HC, Nyangoma SO, Cromie D, Olson JA, Leese GP, Black M. Diabetic retinopathy at diagnosis of type 2 diabetes in Scotland. Diabetologia. 2012;55(9):2335-42.

18. Buková L, Galajda P, Mokáň M. Prevalence of diabetic retinopathy and distal symmetrical diabetic polyneuropathy, and glomerular filtration screening upon the diagnosis of type 2 diabetes mellitus - a cohort study. Vnitr Lek. 2013;59(11):955-60.

19. Al-Zuabi H, Al-Tammar Y, Al-Moataz R, Al-Sabti K, Wani VB Hamama F. Retinopathy in newly diagnosed type 2 diabetes mellitus. Med Princ Pract. 2005;14(5):293-6.

20. Mahar PS, Awan MZ, Manzar N, Memon MS. Prevalence of type-II diabetes mellitus and diabetic retinopathy: the Gaddap study. J Coll Physicians Surg Pak. 2010;20(8):52832.

21. Hayat AS, Khan AH, Baloch GH, Shaikh N. Frequency and pattern of retinopathy in newly diagnosed type 2 diabetic patients at tertiary care settings in Abbottabad. J Ayub Med Coll Abbottabad. 2012;24(2):87-9.

22. Manaviat MR, Afkhami M, Shoja MR. Retinopathy and microalbuminuria in type II diabetic patients. BMC Ophthalmol. 2004;4:9-10. 